\title{
CONTENTS
}

Acknowledgments vii

Introduction 3

PART I: DESIGNING TASKS FOR MINDFUL WRITERS

1 What Does It Mean to Teach Writing? 15

2 The Content of/Is Writing 26

3 Metacognition and Mindful Writing

4 The Learning Cycle for Mindful Writers 43

5 Meaningful Writing Tasks 48

6 Organizing Writing Tasks 61

7 Writing as (Meta)Thinking 69 Interlude: The First Day 75

PART II: PLAN

8 Planning and Thinking 83

9 Assess the Task 88

10 Set Goals

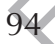

\section{PART III: PRACTICE}

11 The Essence of Teaching 99

12 The Lesson Plan 103

13 Daily Writing 110

14 Models (Or How to Teach Anything) 119

15 Class Discussion 131

16 Collaborative Learning 142

17 Teaching Reading 151

PART IV: REVISE

18 Revision as Mindful Writing 165 
19 Responding to Mindful Writers 175

20 Grading Mindful Writers 187

21 Peer Feedback 195

22 Mindful Style 203

PART V: REFLECT

23 Reflection as Mindfulness 221

24 The Reflective Course 231

PART VI: THE MINDFUL TEACHER

25 Mindful Teaching 239

26 Community 253

References 265

About the Author 283

Index 285

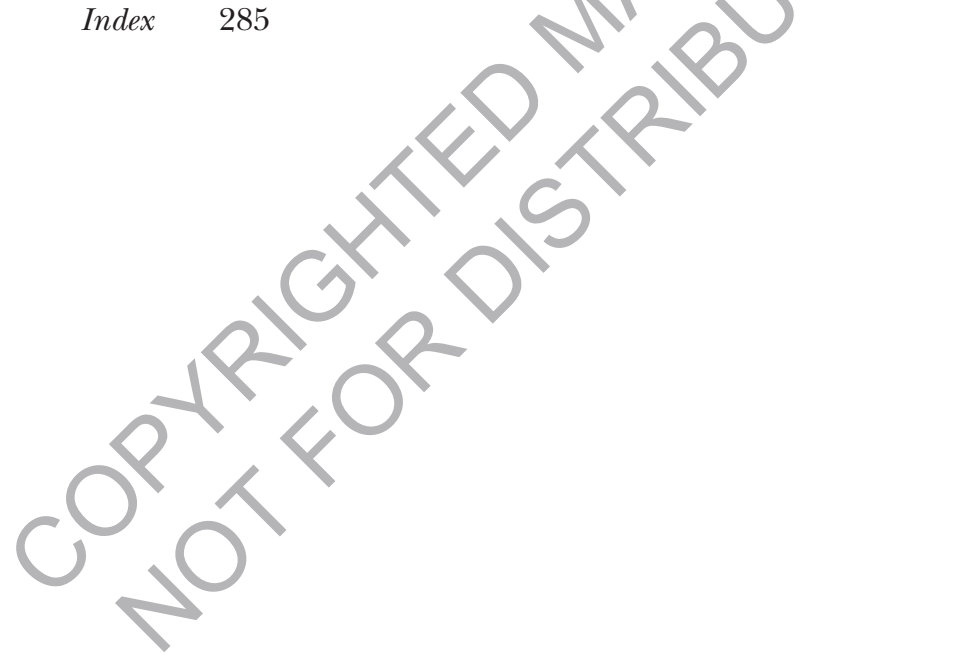




\section{INTROD UCTION}

Years ago I had a student named Michael in my first-year writing class who was struggling through an awakening. He'd been a good writer all his life: always wrote with confidence bordering on snarkiness, never had to revise his first drafts much, always received praise and As from English teachers. He spent (by his own admission) very little time on our first assignment-an opinion editorial for our university's newspaper-and he'd been unpleasantly surprised at my tepid response to his draft.

In a one-on-one conference with him, I learned that Michael was beginning to think thoughts he'd never thought before about writing and about himself as a writer. His first realization went something like this: The writing process I've been using all my life is inadequate for this class. This was a scary admission. If a tried-and-true method of success wasn't working in a writing class, what else was broken?

His second realization was more other-directed: I can't continue to write for my own amusement - I have to think about a reader. On his draft, I had asked him questions about what his student audience might think about the force of his argument, his irrepressible self-confidence, his denigration of the opposing views that surely would be held by many of his readers.

At the time, Ididn't have the teaching tools to explain to Michael what was happening to him. He was becoming self-aware as a writer. More deeply, he was becoming a philosopher of his own learning and thus owning his learning in a way he hadn't before. It seems not to have occurred to him-and frankly it never occurred to me when I was a first-year college student-that we can think "meta" about ourselves as writers in the middle of a writing task, almost like we're jumping out of our bodies to observe and analyze and make adjustments to the writing behavior we see in ourselves.

Teaching Mindful Writers is about how we can make sure that all our students have this "meta" experience thinking about themselves as writers in the act of writing.

$$
* * *
$$


As a writing teacher you've chosen to help people develop skills and habits of mind that will make their lives more rewarding. In the myth of the hero's journey, you are the wise wizard distributing magic cloaks or better swords or healing potions to the brave soul who has left home seeking adventure and challenge. In your role as writing teacher, you are Galadriel, the Elf Witch.

I have been teaching college writing for seventeen years now. On the second day of my first semester teaching, on the day after the September 11, 2001, terrorist attacks on New York City and Washington, DC, the power went out in the classroom I was teaching in, rendering the only materials I'd prepared-two transparency slides-useless. Whatever I did that day as Plan B was swallowed up by collective anxiety and mourning. It was a rough start. Since then, I've taught hundreds of writing students and observed over 300 first-year writing teachers teach, and I can say with confidence that there are better and worse ways of teaching writing. In this book, I want to share what I've learned about how to teach students metacognitive habits that might stay with them after they leave your class.

This is a book for teachers of first-year writers. Specifically, this book is about how to design a major writing task so that your students become mindful, self-directed writers. While I focus on what might be called the instructional design of a single unit, I hope to share insights into other important dimensions of teaching writing, and there are many-in fact too many for my meager talents to treat. I've borrowed and remixed and repurposed from wonderful mentors over the years. Now I'm passing that mixtape to you.

I've written Teaching Mindful Writers with several assumptions that have influenced what I decided ultimately to include or not include. Here they are.

\section{NEW(ISH) TEACHERS OF FIRST-YEAR WRITING (FYW)}

While this book is for anyone teaching writing at any stage in a career, I've written this book with a specific kind of teacher in mind: the rookie first-year writing teacher. I assume, first, that you are relatively new to the teaching profession-perhaps a student in a graduate program. Second, I assume you are a writing teacher for first-year students-students who are likely young and/or new to college life. (In 2017, around 40 percent of college students were over twenty-five. See "Fast Facts" 2018.)

If, in fact, you are a rookie teacher, then chances are you have already been given a set of outcomes, policies, assignments, texts, a learning 
management software, maybe even a standard syllabus. I imagine at this moment you are building your teaching expertise by learning to teach in a specific community of practice at your institution. Because of that arrangement, I will not cover a variety of topics (like how to build a syllabus or form a plagiarism policy) covered quite well in books such as The St. Martin's Guide to Teaching Writing (Glenn and Goldthwaite 2014), now in its seventh edition.

\section{THEORY, HISTORY, RESEARCH}

Good teachers seek out the published wisdom of the field. Writing pedagogy has its own library of theory, history, and research, and no matter what your academic emphasis (linguistics, creative writing, literature, rhetoric), you should become familiar with it. In every chapter that follows, I synthesize some of the voluminous research on teaching writing. However, since many of you will be taking, or will have already taken, a required graduate course in rhetoric and writing studies, I'm not trying to be comprehensive. Excellent sources already exist for that kind of reading, for example Oxford's Guide to Composition Pedagogies (Tate et al. 2014) or the huge Norton Book of Composition Studies (Miller 2009), or Exploring Composition Studies (Ritter and Matsuda 2012), or Concepts in Composition (Clark 2012), or Cross-Talk in Comp Theory (Villanueva and Arola 2011) or A Rhetoric for Writing Teachers (Lindemann 2001). You will have to cut back on sleeping, eating, and going to the bathroom if you want to get all this reading done, but hey, no sacrifice too great for the writers of tomorrow. These books establish the theoretical paradigm for teaching writing of which this book will give you just a taste.

\section{PRACTICE, PraCtICE, PRACTICE}

Any teaching practice is informed by theoretical assumptions, whether self-consciously applied or not. While I will be sharing research and theory with you, I also assume that what's more appealing to you as a teacher is a list of teaching ideas that will help you immediately. Therefore, I've tried to keep the chapters short and full of ideas for the kind of "just in time" teaching FYW teachers need to master. These ideas come from a variety of places: my own experience as a teacher, the stuff I've ripped off from other amazing teachers, rigorous research, conventional wisdom, professional training or publications, my observations of other teachers, and so on. Many of these principles will work well for you; some won't 
and should be discarded or revised based on your experience and the philosophies you develop as an educator.

On that last point, I admit at the start that I tend to be an overdetermined writing teacher, meaning that often I want to control the learning experience more than I should. More experienced teachers-more intuitive and expressive and open and decentered teachers-may find some of what I propose in this work, if taken as an explicit recipe for teaching, to be stifling, and I'm sympathetic to that view. So, when it comes to the learning model I propose, decorate your teaching bower with what strikes your fancy. Aristotle talks about rhetoric not as persuasion but as "discovering the available means" of persuasion. Think of this book as a storehouse of ideas for discovering the available means of teaching mindfulness to student writers.

\section{APPROACHES TO FYW}

I assume that what I share with you can work for a variety of contents, students, and teaching situations. Like the "teaching for transfer" (TFT) model presented by Kathleen Blake Yancey, Liane Robertson, and Kara Taczak in the now indispensable Writing across Contexts (2014), I hope that what I'm sharing in this book willfit any of the approaches to FYW you might be teaching, and there are dozens: academic writing, personal writing, public argument, genre analysis, critical cultural studies, online classes, developmental or second language writing, advanced or disciplinary writing, writing about writing, writing about literature, firstyear seminars, and so forth.

While this model is generic enough to fit a variety of writing courses, I do advocate for specific content knowledge that I think should be part of every writing course. I've been convinced by recent research on content in FYW (like the Writing about Writing movement, e.g., or genre studies) that there are some things students need to understand to be effective writers in any setting. This content provides what Kenneth Burke called "equipment for living" (1973, 293)-useful paradigms for living wisely. The content of writing is writing (see chapter 2). Surely you will develop your own content base as you continue to teach, and that content base likely will be informed by whatever branch of language studies you've chosen to specialize in. However, I argue that if you teach FYW, you should think of yourself as a teacher of rhetoric and writing knowledge and teach that knowledge to your students, no matter what reading or writing you assign. 


\section{YOUR STUDENTS}

This book, which I hope might be helpful to any instructor teaching anywhere, reflects my own limitations as a writer, scholar, and teacher. While half of all postsecondary writing students are in two-year colleges (Toth, Sullivan, and Calhoon-Dillahunt 2019, 86), I have taught only at four-year institutions. In graduate school I taught at a university in the Southwest at which people of color made up a little over 40 percent of the student population. Since then, I've taught at a highly selective religious institution whose student population hovers at around 80 percent white, as I am. I am still learning the extent to which my perspective constrains my approach to teaching writing.

Considering my limitations, then, I expect moments when my passionate declarations about "best" teaching practices may seem to many of you misguided-heck, even irrelevant-considering the students you teach and your own identity as a teacher. Those moments are important for you, and for me. Therefore, 1 strongly encourage you to participate in professional conversations that consider diverse student populations' interests. For example, if you teach mostly students who are learning English as a second, foreign, or additional language, you will want to complement what you get here with a book such as Dana Ferris and John Hedgcock's Teaching 22 Composition, now in its third edition (2014), or the NCTE publication Second-Language Writing in the Composition Classroom (Matsuda et al. 2010). Our professional society, the Conference on College Composition and Communication, has issued a statement urging writing teachers and programs to develop instructional practices and têcher training programs in "second-language writing theory, research, and instruction" ("CCCC Statement" 2011, 11). If you're teaching, or plan to teach, at a two-year college, I suggest you balance what might be considered my "four-year-centric" approach (Toth, Sullivan, and Calhoon-Dillahunt 2019, 93) with scholarship like the "TYCA Guidelines for Preparing Teachers of English in the Two-Year College" (2016).

\section{TECHNOLOGY}

About technology, I am mostly mum. We are in an age of acceleration, an age in which Moore's law about computing power tells us that all we can predict about the future of media is that it will be unpredictable and exponentially dynamic (see Friedman 2017). To some degree I am assuming that the research-based teaching practices I promote in this book are tech-invariant. The website No Significant Difference, 
edited by Thomas Russell, is a gravesite of studies showing that different technologies have little effect on learning. That said, we cannot plunge into teaching writing without addressing the technologies we use to write, since "technologies influence the situation, form, and production of texts" (Bazerman 2016, 12). Considering the wide range of options and approaches, I've opted to say little specifically about digital writing, multimodality, online courses (even though I have designed one-admittedly not a great one), mobile composing, social media, design, or online collaboration. The teaching principles I share here can be applied in classes with a variety of tech commitments, but it is wise for us to prepare to adjust our approaches as new technologies create new literacy practices. If you feel like this tech evasion is, well, an evasion, please seek out some of the excellent literature on teaching and technology.

\section{SCOPE}

Finally, and most important, I believe that what FYW can offer the world is paradoxically more modest and more profound than has been assumed. Administrators and parents and members of the public expect FYW to be everything to everyone: to teach voice, correct sentences, research writing for all disciplines, a coherent argument, citation, paragraphing - "the full catastrophe," as Zorba the Greek would say. In The Chronicle of Higher Education, Doug Hesse, a writing program administrator at the University of Denver (UD), wrote about hearing from several faculty members across campus that UD students "can't even write a decent sentence." Hesse ended up coding 500,000 words of student writing just to demonstrate, in a cheeky way, that more than 90 percent of the sêntences were actually "clear and error-free"-not a bad definition of decent (Hesse 2017). When I started running our writing program, I was asked by a senior colleague whether we were teaching our FYW students the difference between infer and imply. Another, from a different college on campus, asked me why we don't teach students how to analyze visual data. It is a wonder we are not criticized for neglecting first aid or auto repair.

Let's put aside this all-too familiar criticism. We know we can't teach everything about writing to our students, and we shouldn't tell people we can. But perhaps we can teach them practices that will help them inhabit mindfully any important writing task they encounter. What I'm trying to do here is focus on one aspect of teaching that I believe has become even more important in the last few years as we have studied 
how people learn to write and how they take what they've learned into new settings. The big picture that emerges from this scholarship is this: What we ask students to think and write about before, during, and after they complete a major writing task is just as important as that final product they turn in for grading. In other words, what students produce is not more important than the kind of writer the process produces. And I will make the case in this book that effective writers are effective metacogs, that is, mindful writers. We can offer the world this much, and maybe not much more.

I believe we can be better at teaching our students to approach every writing task with a mindful and deliberate disposition. Specifically, we can teach them how to set their own goals, practice writing strategies, make self-directed adjustments, and then reflect on their new skills. The model for self-directed writers I am proposing involves those four practices: planning, practicing, revising, and reflecting. This process is at the heart of a well-organized curriculum for a major writing task. We will discuss each dimension in separate parts. While this may sound like the old writing process model-prewrite, draft, revise-it is a significant overhaul, in this sense: While the old model concentrated on how students complete a writing task, this new model focuses on the habits of mind effective writers adopt through the whole process, whether they follow these activities in a linear or more creative, recursive way. The new model teaches students to be philosophers of their own learning.

I hope teaching writing will be as intellectually and personally rewarding for you as it has been for me. I know some of you are just passing through, teaching FYW while you complete a dissertation on digital humanities or African American literature. No matter the reason, you're one of ours now-Team FYW Forever. If your graduate program is like most others in the United States, no matter the discipline, you will not spend much time in your coursework-maybe not any time-studying how to teach or receiving feedback on teaching in your discipline. However, most writing programs require their teachers to take a summer training seminar, a course, and/or some in-service training on teaching writing. I hope I can help in this effort to launch you into your teaching.

In part I, I want to establish some of the groundwork on metacognition, course design, and the content of writing. Our goal as writing teachers is not merely to teach students how to write decent sentences; in fact, it would be more exciting, and perhaps more useful, to teach them to write indecent ones. Rather, we want students to develop a kind of wisdom about their communication practices. We want them 
to understand the principles underlying effective writing and know how and when to apply them. In the words of John Dewey, whose work has informed mine since graduate school, this kind of understanding "enables us to direct our activities with foresight and to plan according to ends-in-view" (Dewey 1986, 125; see also Wiggins and McTighe 2005, 39). Such "deliberate and intentional" use of knowledge constitutes what I call mindful writing, which is a form of metacognition meant to help students monitor and control their writing process for social ends.

To develop mindful writing as a habit of action enduring beyond our classes, students need to practice a variety of mini-interventions into their processes-stepping away from the process, taking their heads off and peering inside into their learning, tapping their wiser, more "meta" selves. In parts II-V, I describe the four dimensions of mindful writing identified as planning, practicing, revising, and reflecting. This model does not represent a linear, lockstep sequence but a set of necessary interventions that will help students develop the habits of mind we want them to have. Nor is this model original with me-its components have been around since early research on cognitive development and writing. I want to share this pedagogical content knowledge with teachers like you to help you design writing tasks that transform students into active learners. In part III, I will divert somewhat from the mindfulness track to talk about specific teaching practices (e.g., leading class discussion) that can refine the way we teach our novice writers.

In part VI, "The Mindful Teacher," I share a few thoughts about what it means (to me) to be a teacher and how we can get better at our work. I admit here that I haveso much to learn myself. When you run a writing program, you risk hypocrisy every time you dispense teacherly wisdom. For example, I'm fond of encouraging grad student instructors to keep class discussions brief and focused on a specific writing-related goal (see chapter 15). But I'm also fond of the entirely unpredictable, emotionally gratifying, free-ranging, time-killing full-class discussions that often result from a particularly good reading or student question. You're in the presence of a flawed-but I hope not unreliable-narrator.

I believe, strongly, that, like writing itself, teaching writing is not perfectable (Wardle and Downs 2017, 15). Even so, having read more than my fair share of research on it, and having observed hundreds of hours of it and analyzed hundreds of student-generated writing and ratings, I can tell you that some teaching methods empower students and others do not. Teaching is an intellectual activity informed by an interdisciplinary, mixed-method inquiry into its craft and consequence. (In that Chronicle article I mentioned above, Hesse points out that "we 
know what works" in teaching writing because we have decades of good research on it.) We are not babysitters or stand-up comedians or bookclub leaders. We are teachers. What we do influences the lives of other people and contributes to their well-being-in-the-world. In spite of the funeral dirges we often hear for the written word (e.g., Manjoo 2018), reading and writing text empowers us, delights us, helps us connect and convince. That is the work we have chosen to do.

Let's get to work.

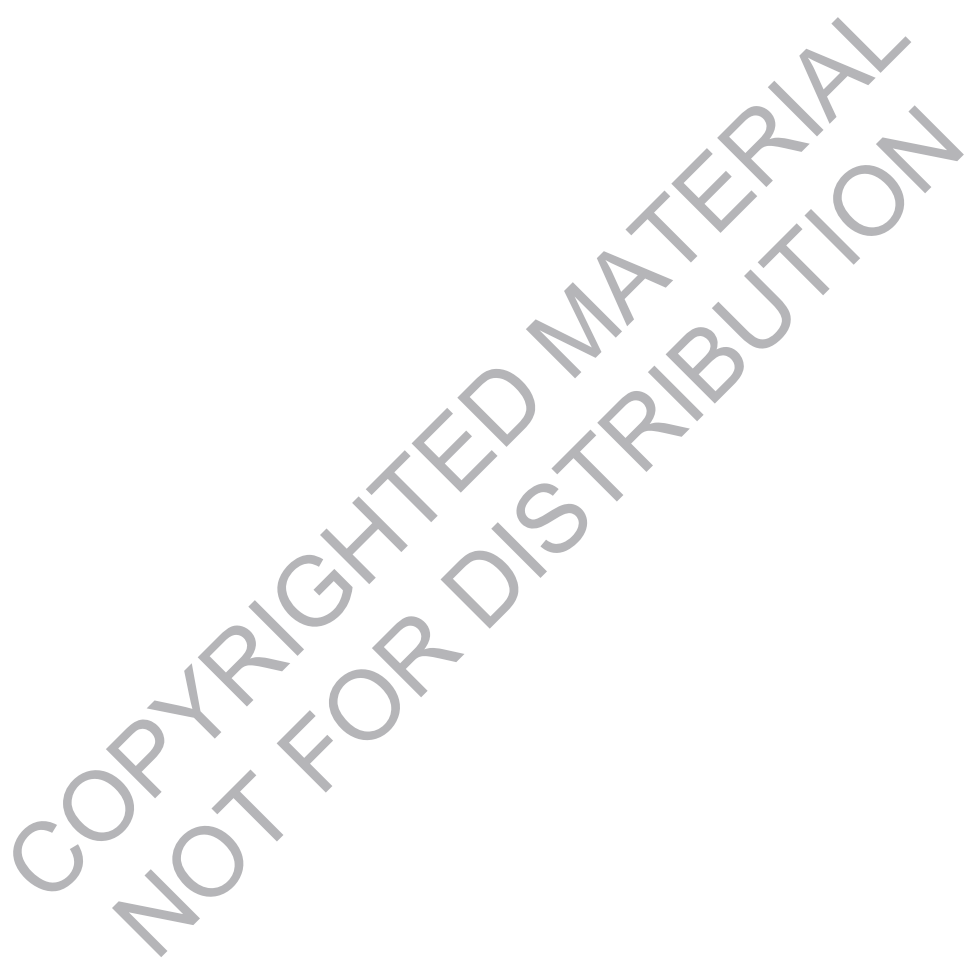

